\title{
On-road exhaust emission testing
}

The paper presents the reasons behind on-road vehicle exhaust emission testing. The latest legislation has been presented in the paper applicable in the EU as well as the research potential of the Institute of Combustion Engines and Transport of Poznan University of Technology. The presentation of the results of the on-road tests pertains to passenger vehicles, buses and non-road machinery (construction machinery, tractors) and aircraft. The comparison of the exhaust emissions from different means of transport under real traffic conditions constitutes an important trend included in the normative legislation related to exhaust emissions.

Key words: exhaust emissions, vehicle testing, on-road testing, real traffic conditions

\section{Badania emisji pojazdów w rzeczywistych warunkach ruchu}

\begin{abstract}
$W$ artykule zaprezentowano przyczyny podejmowania badań emisji spalin z pojazdów $w$ rzeczywistych warunkach ruchu drogowego. Przedstawiono najnowsze przepisy prawne obowiazujące w Unii Europejskiej oraz podano możliwości badawcze Instytutu Silników Spalinowych i Transportu Politechniki Poznańskiej w zakresie badań drogowych różnego rodzaju pojazdów. Prezentacja wyników badań drogowych dotyczy samochodów osobowych, autobusów, a także pojazdów pozadrogowych (maszyn drogowych, ciagników) oraz samolotów. Porównanie emisji zanieczyszczeń różnych środków transportu w rzeczywistych warunkach ruchu stanowi docelowo ważny kierunek rozwoju ujęty w najnowszych przepisach normatywnych dotyczacych tego zagadnienia.
\end{abstract}

Słowa kluczowe: emisja spalin, badania pojazdów, rzeczywiste warunki ruchu

\section{Introduction}

The basic factor deciding about the advancement of technology in all branches of industry is the need to reduce its negative impact on the natural environment. The use of advanced technologies and their development force the engineers to constantly evaluate the conditions of operation of machines and equipment as well as their impact on the natural environment. Besides, the improvement of the classic powertrain (combustion engines) research works have been conducted with a view to finding alternative sources of propulsion. Based on current analyses we can state that by 2050 combustion engines will still be a prevailing source of propulsion (Fig. 1).

\section{Wstęp}

Podstawowym czynnikiem rozwoju techniki i technologii we wszystkich dziedzinach przemysłu jest konieczność ograniczania jego negatywnego wpływu na środowisko naturalne. Stosowanie zaawansowanych technologii i ich rozwój zmuszają do ciągłej weryfikacji istniejących warunków pracy maszyn i urządzeń oraz skutków ich wpływu na środowisko naturalne człowieka. Poza doskonaleniem klasycznego napędu (silnik spalinowy) prace badawcze prowadzi się również w kierunku poszukiwania napędów alternatywnych. Opierając się jednak na dotychczasowych analizach, można stwierdzić, że do roku 2050 będą nadal dominować silniki spalinowe (rys. 1).

\section{Types of exhaust emission testing}

The control of the exhaust emission level can be done in homologation tests on a chassis or engine dynamometer and, more frequently so, on the road, under real traffic conditions, let alone the method of estimation through on-board diagnostic devices (Fig. 2) [7].

The exhaust emissions from vehicle engines are constantly reduced through an introduction of ever better engine and exhaust system design solutions. The main reason for these actions is the evolution of the vehicle and engine emission legislation, particularly in the US, Japan and the European Union. Some countries, other than those listed above introduce their

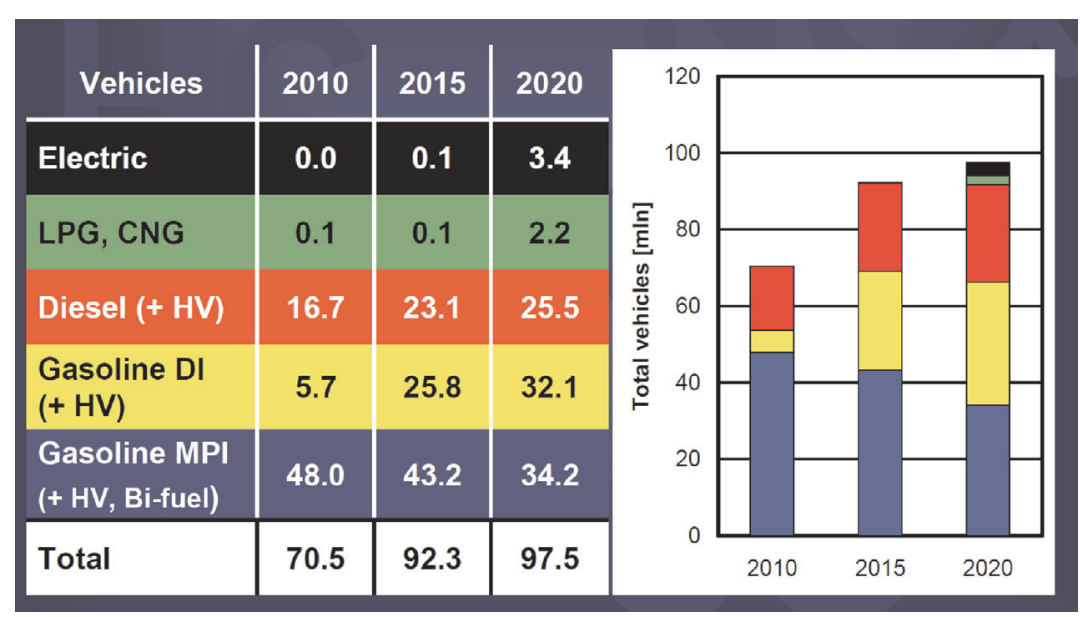

Fig. 1. Forecasted passenger vehicles in the world by 2020 [10]

Rys. 1. Przewidywana struktura samochodów osobowych na świecie do roku 2020 [10] 


\section{Exhaust emission tests}

1. Homologation

(chassis and engine dynamometers)

2. Periodic inspections

at inspection stations

3. On-road tests

(real traffic/operating conditons)

4. Remote sensing technology

Fig. 2. Exhaust emission testing

Rys. 2. Badania związków toksycznych spalin

\section{Rodzaje badań emisji spalin}

Kontrola poziomu emisyjności pojazdów może odbywać się podczas badań homologacyjnych na hamowni podwoziowej lub silnikowej oraz - w coraz większym zakresie podczas badań w rzeczywistych warunkach ruchu, a także szacunkowo - z wykorzystaniem systemów diagnostycznych bezpośrednio w pojazdach (rys. 2) [7].

Emisja związków szkodliwych z silników samochodowych jest ciągle zmniejszana przez wprowadzanie coraz lepszych rozwiązań konstrukcyjnych w silnikach oraz układach wylotowych. Głównym powodem tych działań jest rozwój przepisów dotyczących dopuszczalnej emisji z silników i samochodów, szczególnie w USA, Japonii i Unii Europejskiej. Niektóre państwa, poza wymienionymi, wprowadzają przepisy z opóźnieniem (rys. 3), wzorując się na przepisach europejskich lub amerykańskich. Wprowadzenie od roku 2010 w Europie nowych limitów dotyczących emisji związków szkodliwych w spalinach: Euro 5 i Euro 6 (od 2014 r., z nowymi metodami badawczymi

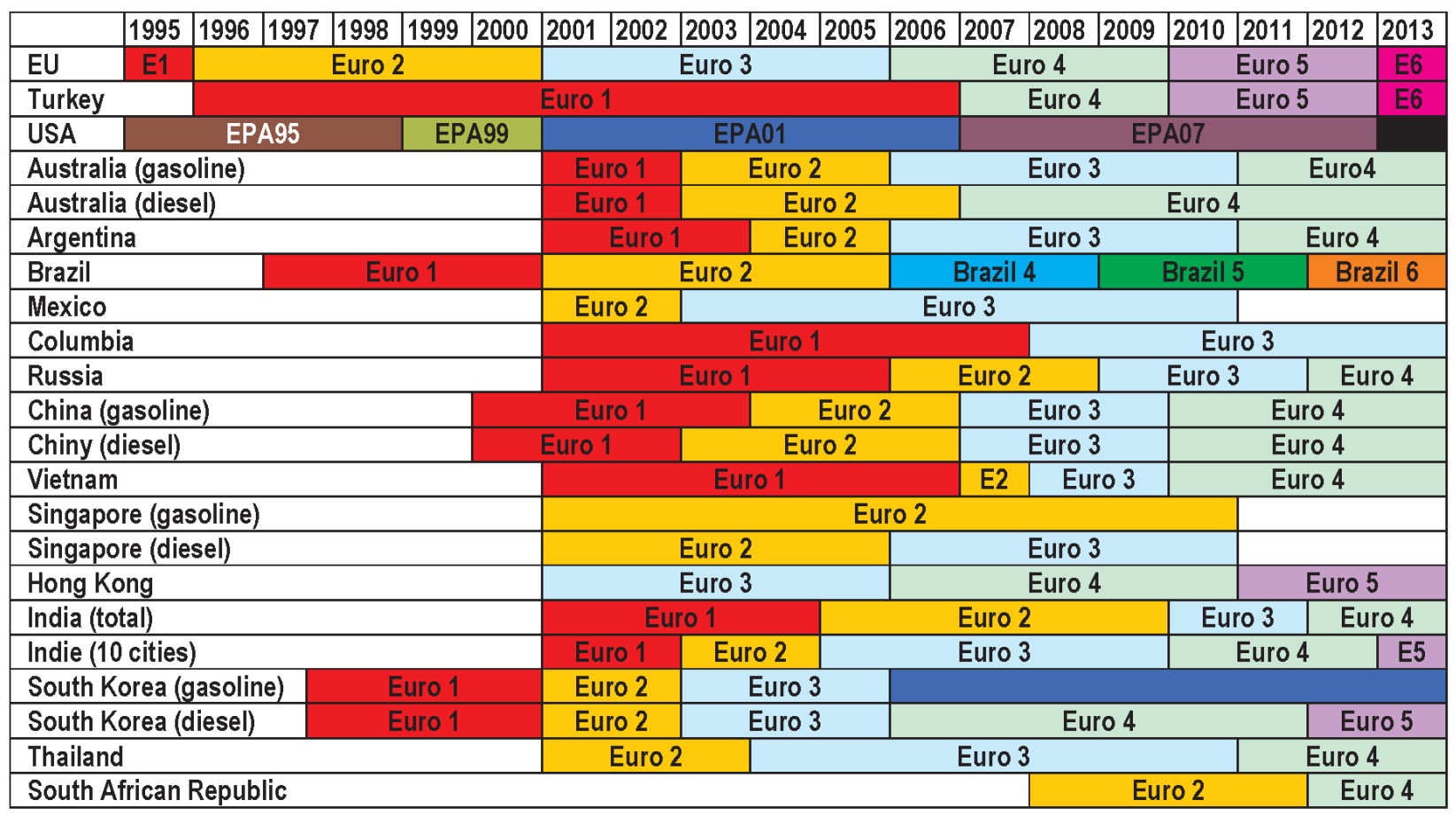

Fig. 3. Versatility of the world emission standards

Rys. 3. Różnorodność światowych przepisów emisyjnych

legislation with delay (Fig. 3) drawing on the European or American legislation. The introduction in Europe in 2010 of new exhaust emission limits: Euro 5 and Euro 6 (from 2014 with new testing methods related to the on-board diagnostics) requires a development of a new generation of engines and further advancement of the aftertreatment systems under all operating conditions. More attention is being drawn to the necessity of developing the testing methods so that they more accurately reflect the on-road operating conditions of engines and vehicles and developing tests that do not require dismounting of engines from vehicles $[9,13]$. dotyczącymi diagnostyki pokładowej) wymaga opracowania nowej generacji silników i dalszego rozwoju konstrukcji układów obniżających emisję szkodliwych składników spalin w każdych warunkach pracy silnika. Coraz większą uwagę zwraca się również na zbliżenie proponowanych metod badawczych do rzeczywistych warunków eksploatacji silników i samochodów oraz opracowanie tanich testów badawczych niewymagających demontażu silnika z pojazdu $[9,13]$. 


\section{Tests under real traffic conditions}

\subsection{Methodology of testing using PEMS}

European legislation related to the exhaust emissions is subject to constant and frequent changes. Directive 70/220/ECE for light duty vehicles ever since its introduction in the 1970 s of the last century has been modified 19 times. The European Union has recently prepared a package of new exhaust emission legislation for motor vehicles - the Euro 5 and Euro 6 standards. The first of these acts has already been published, regulation 2007/46/ EU of the European Parliament and the European Council that provides for the possibility of control of the exhaust emissions with the use of on-board diagnostics. Also, recommendations were included that allow an extended control of the emission under real traffic conditions (aside from the homologation tests) by Portable Emissions Measurement Systems for combustion engines in all types of transport [1]).

As for heavy duty vehicles in the new legislation significant changes were introduced in relation to the Euro V emission standard compliance.

The vehicle manufacturer should perform the first compliance tests within 18 months from the registration of the first vehicle fitted with the homologated engine. The tests should be repeated within a minimum of two years in the normal vehicle life cycle. The tested vehicle mileage should be at least $25000 \mathrm{~km}$.

The tests are conducted in a regular traffic. They are divided into three types:

- Urban cycle- vehicle speeds in the range of 0-50 km/h,

- Extra urban cycle- vehicle speeds in the range of 50-75 $\mathrm{km} / \mathrm{h}$,

- Expressway cycle- vehicle speeds higher than $75 \mathrm{~km} / \mathrm{h}$.

The share of the individual cycles depends on the vehicle category.

The duration of the driving cycle should be selected so that the total work or mass carbon dioxide emission is 5 times higher than in the WHTC cycle.

The measurement of the following engine and vehicle parameters is required: the concentration of THC, $\mathrm{CO}, \mathrm{NO}_{x}$, $\mathrm{CO}_{2}, \mathrm{CH}_{4}$ in the exhaust gases (only in tests of vehicles fueled with gaseous fuels; the PM mass and number are not included in the test), exhaust mass flow, engine torque and speed, vehicle speed, vehicle GPS position (longitude and latitude), fuel mass flow, ambient pressure and temperature, coolant temperature, intake air temperature.

The tests are conducted with the use of a portable exhaust emission analyzer - PEMS. In principle the device enables the measurement of all the mentioned engine and vehicle parameters. It is however admissible to use the data (torque, engine speed, vehicle speed, fuel mass flow, coolant temperature) from the on-board diagnostics. The legislation says that the data be fed by the on-board computer and recorded by the PEMS.

For the determination of the compliance of a vehicle in operation with the exhaust emission requirements a conformity factor is used. Through PEMS, in the whole driving

\section{Badania w rzeczywistych warunkach ruchu}

\subsection{Metodyka badań emisji z PEMS}

Europejskie przepisy dotyczące emisji zanieczyszczeń podlegają ciągłym i częstym zmianom. Dyrektywa 70/220/ EWG dla pojazdów lekkich od wejścia w życie na początku lat siedemdziesiątych XX w. była znowelizowana 19 razy. Unia Europejska przygotowała obecnie pakiet nowych przepisów dotyczących emisji zanieczyszczeń z pojazdów samochodowych - wymagania Euro 5 i Euro 6. Opublikowano już pierwszy z dokumentów tego pakietu, rozporządzenie 2007/46/WE Parlamentu Europejskiego i Rady, w którym zawarto postanowienia odnośnie do możliwości kontroli emisji z wykorzystaniem pokładowych systemów diagnostycznych. Zawarto również zalecenia pozwalające w większym stopniu kontrolować emisję w warunkach rzeczywistych (poza testami homologacyjnymi) dzięki wykorzystaniu mobilnych analizatorów spalin PEMS (Portable Emissions Measurement Systems) z silników spalinowych wszystkich rodzajów transportu [1].

W odniesieniu do pojazdów ciężkich w nowych przepisach wprowadzono istotne zmiany w kontroli zgodności w eksploatacji w stosunku do obowiązujących dla pojazdów Euro V.

Producent pojazdów powinien przeprowadzić pierwsze badania zgodności w eksploatacji w ciągu 18 miesięcy od rejestracji pierwszego pojazdu wyposażonego w homologowany silnik. Badania powinny być powtarzane nie rzadziej niż co dwa lata w okresie normalnego życia pojazdu. Przebieg pojazdu pobranego do badań powinien wynosić co najmniej $25000 \mathrm{~km}$.

Badania są prowadzone w normalnym ruchu drogowym. Dzieli się go na trzy rodzaje:

- miejski - prędkości jazdy w granicach 0-50 km/h,

- zamiejski - prędkości jazdy w granicach 50-75 km/h,

- autostradowy - prędkości jazdy większe niż $75 \mathrm{~km} / \mathrm{h}$.

Udział poszczególnych rodzajów ruchu w cyklu jazdy zależy od kategorii pojazdów.

Długość cyklu jazdy powinna być tak dobrana, by całkowita wykonana praca lub masowa emisja dwutlenku węgla była pięć razy większa niż w cyklu WHTC.

Wymagany jest pomiar następujących parametrów pracy silnika i pojazdu: stężenia w spalinach $\mathrm{THC}, \mathrm{CO}, \mathrm{NO}_{\mathrm{x}}, \mathrm{CO}_{2}$, $\mathrm{CH}_{4}$ (tylko przy badaniach pojazdów zasilanych paliwami gazowymi; masa i liczba cząstek stałych nie są objęte badaniami), masowego natężenia przepływu spalin, momentu obrotowego i prędkości obrotowej silnika, prędkości jazdy pojazdu, położenia pojazdu (długości i szerokości geograficznej), natężenia przepływu paliwa, temperatury i ciśnienia otoczenia, temperatury czynnika chłodzącego, temperatury powietrza przy wlocie do silnika.

Badania są prowadzone $\mathrm{z}$ wykorzystaniem przenośnego układu do pomiaru emisji zanieczyszczeń PEMS. W zasadzie urządzenie to powinno umożliwić pomiar wszystkich wymienionych parametrów pracy silnika i pojazdu. Dopuszcza się jednak wykorzystanie do określenia momentu obrotowego i prędkości obrotowej silnika, prędkości jazdy pojazdu, natężenia przepływu paliwa i temperatury czynnika 
cycle, the emissions of individual exhaust components are determined expressed as a function of engine operation in $\mathrm{kW} \cdot \mathrm{h}$. The work is divided into portions referred to in the legislation as 'windows'. For each portion an average emission of the individual exhaust components and the realized work are determined. On this basis, unit emission expressed in $\mathrm{mg} /(\mathrm{kW} \cdot \mathrm{h})$ and then the compliance factor $\mathrm{CF}$ as per the formula are calculated:

$$
\mathrm{CF}=\mathrm{e}_{\mathrm{i}} / \mathrm{L}_{\mathrm{i}}
$$

where: $e_{i}-$ unit emission i $[\mathrm{mg} /(\mathrm{kW} \cdot \mathrm{h})], \mathrm{L}_{\mathrm{i}}-$ admissible emission $\mathrm{i}$ in the WHTC test $[\mathrm{mg} /(\mathrm{kW} \cdot \mathrm{h})]$.

The vehicle is deemed as compliant if $90 \%$ of the CF value of the individual driving portions does not exceed 1.5 .

In new legislation the testing methodology for emission requirements compliance in heavy-duty vehicles is different from that used in type approvals. This is a significant difference as compared to the currently applicable principle for both light duty and heavy-duty vehicles. According to that principle the methodology of compliance control and type approval should be identical.

\subsection{On-road testing of passenger vehicles}

The conducted verification tests of passenger vehicle exhaust emissions (gasoline, diesel, CNG, Euro 4 compliant - Fig. 4) under real traffic conditions at the same time constituted an attempt to develop an on-board exhaust emissions measuring system. The determining of the on-road emissions and comparing it with the values obtained on the chassis dynamometer in the homologation test leads us to the emission factor. The calculated emission factor answers the question whether the on-road emissions are comparable with the emissions obtained in the homologation test. At the same time it is the verification of the traffic conditions of the homologation test (developed decades ago) and the real traffic conditions.

The area of increased emission of nitric oxides fall in the range of maximum vehicle speeds and accelerations, hence significant engine loads. It is related to the increased fuel dose and at the same time increased engine speed. In the outstanding areas of vehicle operation for the engine fueled with gasoline the emission level amounts to $0.1-$ $0.3 \mathrm{mg} / \mathrm{s}$ and for the $\mathrm{CNG}$ fueled engine this emission amounts to $0.5-1.5 \mathrm{mg} / \mathrm{s}$. For the chłodzącego danych z komputera pokładowego pojazdu. Przepisy wymagają, by były one dostarczane przez komputer oraz odczytywane i rejestrowane przez PEMS.

Do określenia zgodności pojazdu w eksploatacji z wymaganiami w zakresie emisji zanieczyszczeń służy współczynnik zgodności (conformity factor). Za pomocą PEMS określa się w całym cyklu jazdy emisję poszczególnych zanieczyszczeń wyrażoną $\mathrm{w} \mathrm{mg}$ jako funkcję pracy silnika wyrażoną $\mathrm{w} \mathrm{kW} \cdot \mathrm{h}$. Pracę tę dzieli się na fragmenty zwane w przepisach „oknami” (windows). Dla każdego fragmentu określa się średnią emisję poszczególnych zanieczyszczeń i wykonaną pracę. Na tej podstawie oblicza się emisję jednostkową wyrażoną $\mathrm{w} \mathrm{mg} /(\mathrm{kW} \cdot \mathrm{h})$, a następnie współczynnik zgodności CF zgodnie ze wzorem (1), w którym: $\mathrm{e}_{\mathrm{i}}$ - jednostkowa emisja zanieczyszczenia i $[\mathrm{mg} /(\mathrm{kW} \cdot \mathrm{h})], \mathrm{L}_{\mathrm{i}}$ - wartość dopuszczalna emisji zanieczyszczenia i w teście WHTC $[\mathrm{mg} /(\mathrm{kW} \cdot \mathrm{h})]$.

Pojazd uznaje się za zgodny z wymaganiami, jeśli $90 \%$ wartości CF dla poszczególnych fragmentów cyklu jazdy nie przekracza 1,5 .

W nowych przepisach metoda badań w ramach kontroli zgodności w eksploatacji pojazdów ciężkich różni się od stosowanej w homologacji typu. Stanowi to istotną różnicę w stosunku do zasady obowiązującej dotychczas zarówno dla pojazdów lekkich, jak i ciężkich, zgodnie z którą metody stosowane w kontroli zgodności w eksploatacji i homologacji typu powinny być identyczne.

\subsection{Badania drogowe samochodów osobowych}

Przeprowadzone badania weryfikacyjne emisyjności samochodów osobowych z silnikami spalinowymi (ZI, ZS, CNG, spełniającymi normę Euro 4 - rys. 4) podczas rzeczywistych warunków ruchu drogowego stanowiły jednocześnie próbę stworzenia pokładowego systemu pomiarowego związków szkodliwych. Wyznaczenie emisyjności w warunkach drogowych i porównanie jej z wartościami uzyskanymi na hamowni podwoziowej w teście homolo-
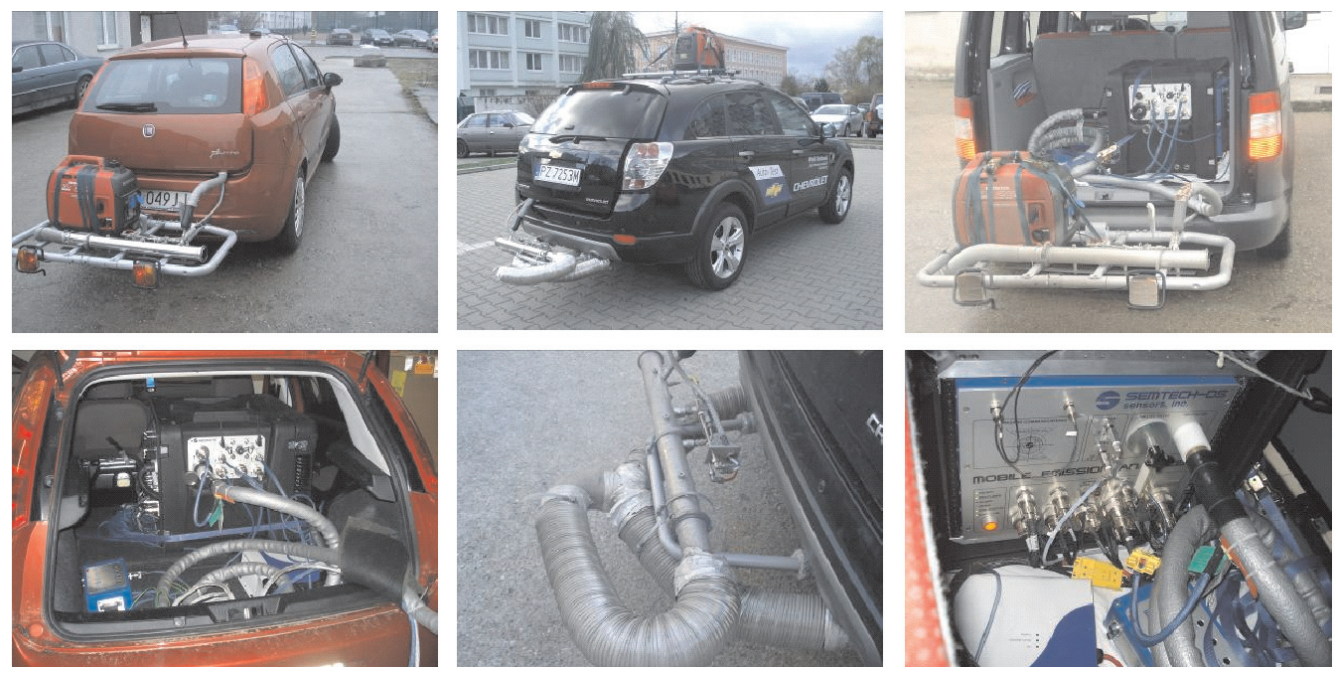

Fig. 4. Passenger vehicles during testing under real traffic conditions (fitted with various engine types: gasoline, diesel, $\mathrm{CNG})$

Rys. 4. Samochody osobowe podczas badań drogowych (wyposażone w różne typy silników spalinowych, zasilane: benzyna, olejem napędowym, $C N G$ ) 
average speeds and accelerations the emission of nitric oxides from a vehicle fueled with $\mathrm{CNG}$ is 5 times higher than for the vehicle fueled with gasoline. For the maximum power the emission of nitric oxides is more than twice as high as the gasoline-fueled vehicle (even though a $10 \%$ lower power is obtained). There are however such engine work points where the emission of $\mathrm{NO}_{\mathrm{x}}$ for a $\mathrm{CNG}$ fueled engine is more than 10 times higher than that of gasoline fueled engine (Fig. 5).

From the emission intensity characteristics we calculate the multiplicity of the increase/reduction of the emission under real traffic conditions as compared to the homologation tests. The vehicle emission index (for a given exhaust component) has been defined:

$$
\mathrm{k}_{\mathrm{j}}=\frac{\mathrm{E}_{\mathrm{rzecz}, \mathrm{j}}}{\mathrm{E}_{\mathrm{NEDC}, \mathrm{j}}}
$$

where: $\mathrm{j}$ - exhaust component for which the emission index was determined, $\mathrm{E}_{\text {rzecz.j }}$ - emission intensity obtained under traffic conditions $([\mathrm{g} / \mathrm{s}]), \mathrm{E}_{\mathrm{NEDC}, \mathrm{j}}$ - emission intensity obtained in the NEDC test $([\mathrm{g} / \mathrm{s}])$. The emission intensity under traf-

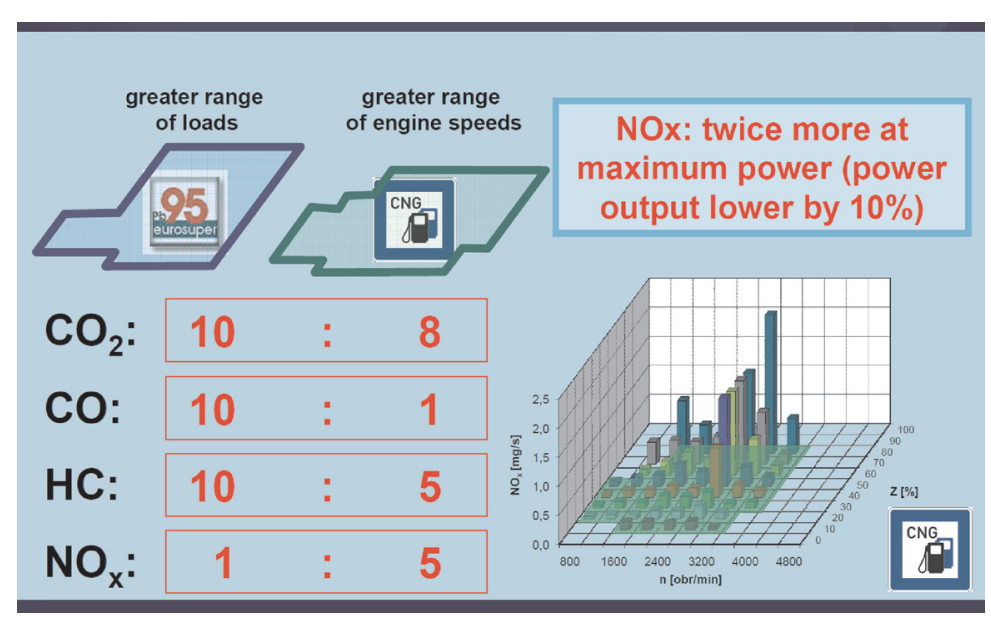

Fig. 5. The share of the operating time of vehicle fueled with gasoline and CNG in the road tests under real traffic conditions

Rys. 5. Udziały czasu pracy pojazdu zasilanego benzyna i CNG podczas badań drogowych w rzeczywistych warunkach ruchu

fic conditions can be calculated using the characteristics of the distribution of the driving time of the vehicle $\left(\mathrm{u}_{\mathrm{a}}, \mathrm{V}\right)$ and the characteristics of the emission intensity of a j-th exhaust component $e_{j}(a, V)$ expressed in grams per second:

$$
E_{r z e c z, j}=\sum_{a} \sum_{V} u_{a, V} \cdot e_{j}(a, V)
$$

If no information is given on the exhaust components in the NEDC test we can adopt the values of the admissible Euro standards that are applicable for a given vehicle. The value of the admissible emission for a given exhaust component given in $\mathrm{g} / \mathrm{km}$ can be converted to (in $\mathrm{g} / \mathrm{s}$ ) if we know the duration (1180 s) and distance $(11,007 \mathrm{~m})$ of the homologation test. Such relations serve to determine the emission indexes of the tested vehicles (Fig. 6). gacyjnym pozwala na określenie wskaźnika emisyjności. Wyznaczony wskaźnik emisyjności służy do odpowiedzi na pytanie: czy emisja w warunkach drogowych jest porównywalna z emisją uzyskiwaną podczas testu homologacyjnego. Jednocześnie jest to weryfikacja warunków jazdy w teście homologacyjnym (opracowanym kilkadziesiąt lat temu) i warunków rzeczywistych ruchu pojazdów.

Obszar zwiększonego natężenia emisji tlenków azotu przypada dla zakresu maksymalnych prędkości pojazdu oraz dla jego przyspieszenia, a więc znacznego obciążenia silnika. Jest to związane ze zwiększeniem dawki paliwa a jednocześnie wzrostem prędkości obrotowej silnika. W pozostałym obszarze pracy pojazdu dla silnika zasilanego benzyną obserwowany jest poziom emisji $0,1-0,3 \mathrm{mg} / \mathrm{s}$, natomiast dla silnika zasilanego CNG poziom emisji wynosi $0,5-1,5 \mathrm{mg} / \mathrm{s}$. Dla średnich wartości prędkości i przyspieszenia emisja tlenków azotu z pojazdu zasilanego CNG jest 5-krotnie większa niż z pojazdu zasilanego benzyną. Dla wartości maksymalnej mocy emisja tlenków azotu jest ponad 2-krotnie większa niż dla silnika benzynowego (pomimo że uzyskuje się moc o 10\% mniejszą). Istnieją natomiast takie punkty pracy silnika, w których emisja $\mathrm{NO}_{\mathrm{x}} \mathrm{z}$ silnika zasilanego CNG jest ponad 10-krotnie większa niż przy zasilaniu benzyną (rys. 5).

Z charakterystyk natężenia emisji oblicza się krotność zwiększenia/zmniejszenia emisji w rzeczywistych warunkach ruchu w stosunku do testu homologacyjnego. Wskaźnik emisyjności pojazdu (dla danego związku szkodliwego) zdefiniowano jako wzór (2), gdzie: j - związek szkodliwy, dla którego określono wskaźnik emisyjności, $\mathrm{E}_{\text {rzecz,j }}$ - natężenie emisji uzyskane w warunkach rzeczywistych ([g/s]), $\mathrm{E}_{\mathrm{NEDC}, \mathrm{j}}$ - natężenie emisji uzyskane w teście NEDC ([g/s]). Natężenie emisji w warunkach rzeczywistych można obliczyć, wykorzystując charakterystykę rozkładu czasu jazdy pojazdu $\left(u_{a}, V\right)$ oraz charakterystykę natężenia emisji dla j-tego związku szkodliwego $e_{j}(\mathrm{a}, \mathrm{V})$ wyrażonego w gramach na sekundę - wzór (3).

Jeżeli nie ma informacji na temat emisji związków szkodliwych pojazdu w teście NEDC, można przyjąć wartości dopuszczalne według normy toksyczności spalin Euro, która obowiązuje dla danego pojazdu. Wartości emisji dopuszczalnej dla danego związku podawane $\mathrm{w} \mathrm{g} / \mathrm{km}$ można przeliczyć na wartości natężenia emisji (w g/s), znając czas trwania (1180 s) i pokonywany dystans (11 $007 \mathrm{~m}$ ) w teście homologacyjnym. Zależności takie służą do wyznaczenia wskaźników emisyjności związków szkodliwych badanego pojazdu (rys. 6).

Uzyskane wartości wskaźnika emisyjności dla pojazdu zasilanego benzyną, olejem napędowym i CNG charakteryzują emisyjność pojazdu w warunkach drogowych w odniesieniu do normy emisji spalin, którą pojazd powinien spełniać. Wartość wskaźnika emisji tlenku węgla $\left(\mathrm{k}_{\mathrm{CO}}=0,3-0,5\right)$ i węglowodorów $\left(\mathrm{k}_{\mathrm{HC}}=0,04-0,1\right)$ dla wszystkich badanych pojazdów świadczy o nieprzekraczaniu średniej emisji tych składników w warunkach drogowych 


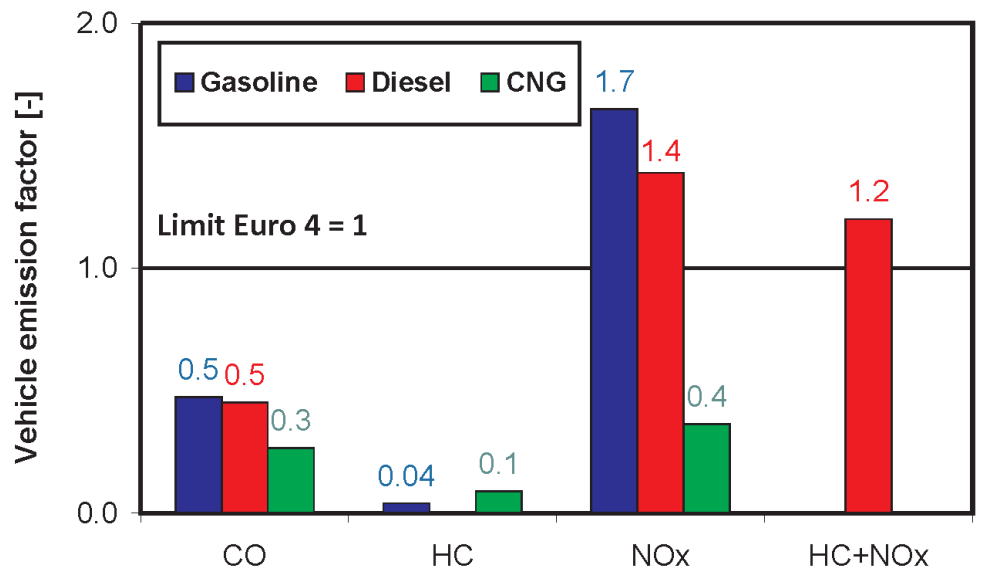

Fig. 6. Comparison of the vehicle emission index with the use of the data on the actual emission in the NEDC test or assuming the values admissible by the standard

Rys. 6. Porównanie wskaźnika emisyjności pojazdu z wykorzystaniem danych o rzeczywistej emisji $w$ teście NEDC lub przyjęciu wartości odpowiadajacych wartościom dopuszczalnym wedlug normy

The obtained values of the emission index for a vehicle fueled with gasoline, diesel oil and $\mathrm{CNG}$ characterize the vehicle on-road emissions in reference to the emission standard that the vehicle should comply with. The value of the emission index of carbon monoxide $\left(\mathrm{k}_{\mathrm{CO}}=0.3-0.5\right)$ and hydrocarbons $\left(\mathrm{k}_{\mathrm{HC}}=0.04-0.1\right)$ for all the tested vehicles confirms that the average on-road emissions are not exceeded in reference to the Euro 4 standard. It is quite contrary in the case of nitric oxides: only for the $\mathrm{CNG}$ fueled vehicle the emission index amounts to 0.4 , which confirms that the emission is lower than that set forth in the standard; For the rest of the vehicles this index amounts to $\left(\mathrm{k}_{\mathrm{NOx}}=1.4-1.7\right)$, hence the average emission is approximately $40-70 \%$ higher than the Euro 4 emission standard allows. For the sum of $\mathrm{HC}+\mathrm{NO}_{\mathrm{x}}$ (Euro 4 standard limits the sum of these components for diesel engines) the emission index is higher than $1\left(\mathrm{k}_{\mathrm{HC}+\mathrm{NOx}}=1.2\right)$, hence the standard (according to which the vehicle was homologated) is exceeded by $20 \%$.

\subsection{Bus on-road testing}

The emission level of city buses due to specific conditions of their operation can only be evaluated when they are used on the road in real traffic. The most adequate tests for buses are the test conducted on their city routes. The tests were performed on a hybrid and conventional bus in city traffic in the Poznan using portable system for the exhaust emission measurement PEMS. The objects of the tests were buses manufactured by Solaris: one unit was fitted with a hybrid powertrain (Hybrid H18) and the other was fitted with a conventional powertrain. The buses were selected based on their similarities (18-meter in length, similar seating capacity) and so that there is a possibility of comparing the functionality and ecological properties of the buses under real w stosunku do normy Euro 4. Odmiennie jest odnośnie do emisji tlenków azotu: tylko dla pojazdu zasilanego CNG wskaźnik emisyjności wynosi 0,4 , co świadczy o mniejszej emisji w stosunku do normy; dla pozostałych pojazdów wskaźnik ten wynosi $\left(\mathrm{k}_{\mathrm{NOx}}=1,4-1,7\right)$, a więc średnia emisja jest o 40-70\% większa w stosunku do normy toksyczności spalin Euro 4. Dla sumy emisji $\mathrm{HC}+\mathrm{NO}_{\mathrm{x}}$ (norma Euro 4 limituje sumę tych związków dla silników ZS) wskaźnik emisyjności wynosi powyżej jedności $\left(\mathrm{k}_{\mathrm{HC}+\mathrm{NOx}}=\right.$ $=1,2$ ), a więc norma (według której był homologowany pojazd) jest przekroczona o $20 \%$.

\subsection{Badania drogowe autobusów}

Emisyjność autobusów miejskich ze względu na specyficzne warunki ich użytkowania można ocenić jedynie podczas rzeczywistego ich wykorzystania. Najbardziej odpowiednimi badaniami dla nich są badania na liniach miejskich. Wykorzystując mobilny system pomiarów związków szkodliwych, dokonano pomiarów emisyjności autobusu hybrydowego i konwencjonalnego w warunkach ruchu miejskiego w Poznaniu. Obiektami badań były autobusy Solaris: jeden egzemplarz wyposażony w napęd hybrydowy (Hybrid H18), a drugi w napęd konwencjonalny. Autobusy dobrano na zasadzie podobieństwa (autobusy 18-metrowe, podobna liczba przewożonych osób), a jednocześnie tak, aby istniała możliwość porównania funkcjonalności i ekologiczności w warunkach rzeczywistych (silniki autobusów spełniały normę toksyczności spalin Euro V).

Porównania dokonano w odniesieniu do emisji jednostkowej (ocenie podlegała masa danego związku szkodliwego w stosunku do energii jaką zużyto podczas każdego badania). Uzyskano następujące wyniki emisji dla autobusu hybrydowego w stosunku do autobusu konwencjonalnego (rys. 7): - duże natężenie ruchu (badania przeprowadzone w piątek): CO

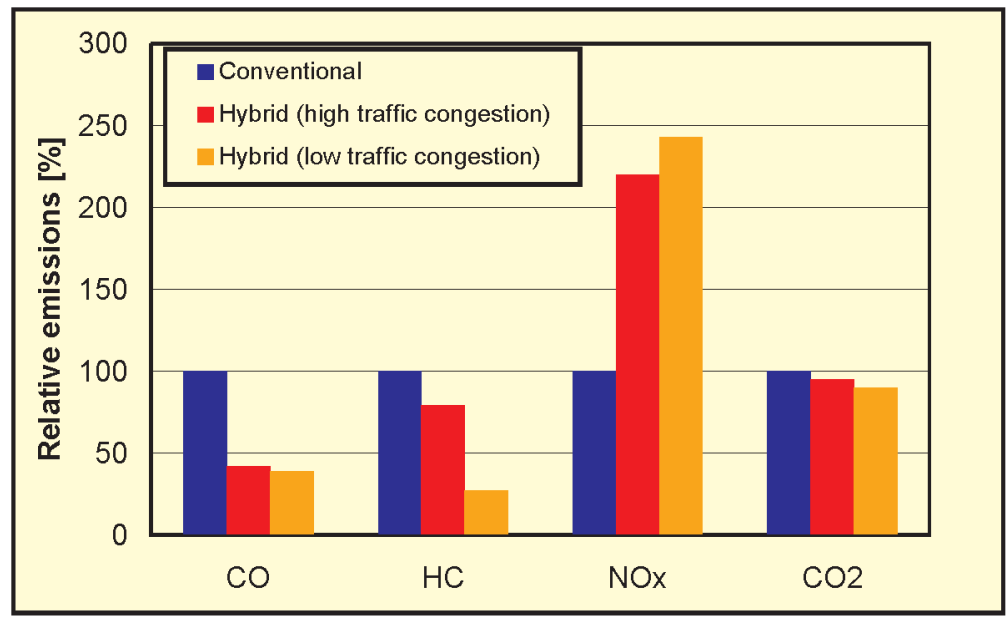

Fig. 7. Relative unit emission of the exhaust components from a hybrid bus as compared to the conventional bus (for which the values of $100 \%$ were assumed)

Rys. 7. Względna zmiana emisji jednostkowej związków szkodliwych autobusu hybrydowego w stosunku do konwencjonalnego (dla którego przyjęto wartości równe 100\%) 
traffic conditions (the bus engines complied with the Euro V standard).

The comparison was made in relation to the unit emissions (the mass of a given component was evaluated compared to the energy used during each test). The following results have been obtained for the hybrid bus as opposed to the conventional bus (Fig. 7):

- high traffic congestion (test performed on Friday): CO lower by $58 \%$, HC lower by $21 \%$, NO higher by $120 \%$, $\mathrm{CO}_{2}$ lower by $5 \%$, fuel consumption- lower by $8 \%$,

- low traffic congestion (test performed on Saturday ): $\mathrm{CO}$ lower by $61 \%$, HC lower by $73 \%, \mathrm{NO}_{\mathrm{x}}$ higher by $143 \%$, $\mathrm{CO}_{2}$ lower by $5 \%$, fuel consumption - lower by $8 \%$. mniejsze o 58\%, HC mniejsze o 21\%, $\mathrm{NO}_{\mathrm{x}}$ większe o $120 \%$, $\mathrm{CO}_{2}$ mniejsze o $5 \%$, zużycie paliwa - mniejsze o $8 \%$,

- małe natężenie ruchu (badania przeprowadzone w sobotę): CO mniejsze o $61 \%$, HC mniejsze o $73 \%$, $\mathrm{NO}_{\mathrm{x}}$ większe o $143 \%, \mathrm{CO}_{2}$ mniejsze o $5 \%$, zużycie paliwa - mniejsze o $8 \%$.

\subsection{Badania pojazdów pozadrogowych}

Transport nadal jest jednym z głównych źródeł emisji związków toksycznych spalin i zużycia paliw kopalnych. Nieracjonalne wykorzystanie ciągników rolniczych do transportowania towarów powoduje negatywny wpływ na środowisko naturalne, jednocześnie zwiększając zużycie
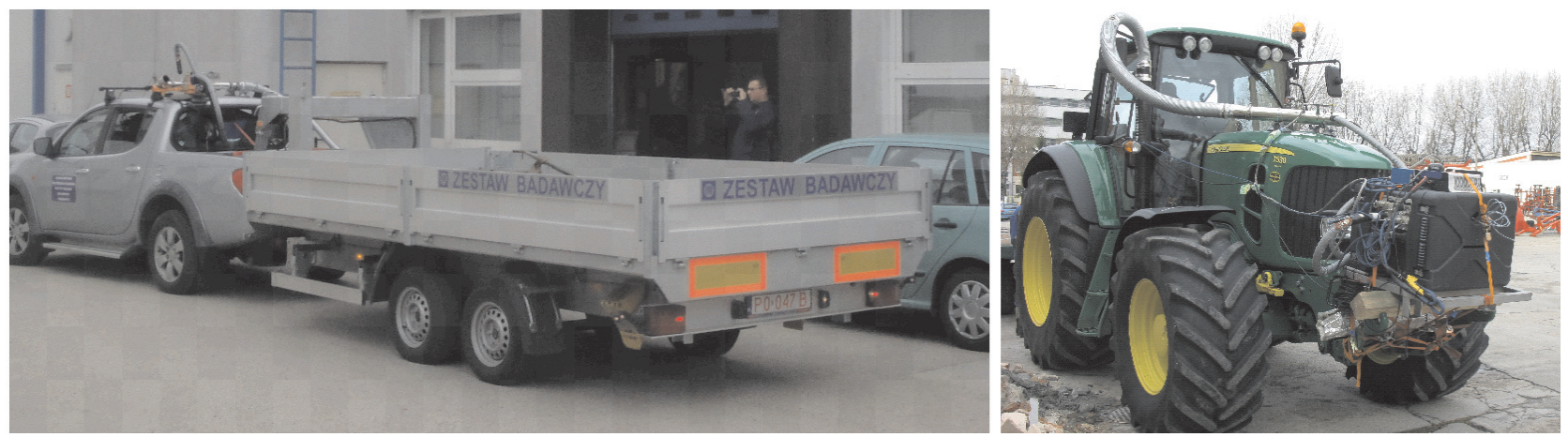

Fig. 8. Vehicles used of the tests

Rys. 8. Pojazdy wykorzystane do badań

\subsection{Non-road vehicle testing}

Transport is still one of the main source of emissions and consumption of fossil fuels. Unreasonable use of farm tractors for transportation of goods results in its negative impact on the environment at the same time increasing the fuel consumption as compared to other means of transport that could carry the same goods (Fig. 8) [5]. A light duty truck coupled with a semi-trailer reduces the time of transport, traffic nuisance due to its higher speeds and generates lower environment pollution.

The tests were performed on a farm tractor and a light duty pickup truck. The engine of the John Deere tractor is a modern unit fitted with the common rail system of the maximum pressure of 1600 bar that realizes multiple injections. The engine is VGT turbocharged. Based on the performed tests under real operating conditions the authors confirmed that the tested vehicle has better ecological parameters than the farm tractor. Analyzing the real emissions from the whole test the authors observed that the pickup truck has a lower emission of all the exhaust components and the emission from the farm tractor was many times higher. The greatest difference was recorded for the emission of $\mathrm{CO}$, which for the farm tractor was over 25 times higher, the emission of $\mathrm{HC}-11$ times higher and the emission of $\mathrm{NO}_{\mathrm{x}}$ almost 6 times higher. But for the emission of $\mathrm{CO}$ of the pickup truck, the emission of all the exhaust components from the pickup truck and the farm tractor exceeded the Euro 4 standards (Fig. 9). The farm tractor also had higher fuel consumption $\left(\mathrm{CO}_{2}\right.$ emission - almost three times higher than for the pickup truck). In the aspect paliwa w stosunku do innych rodzajów transportu tego samego towaru (rys. 8) [5]. Samochód dostawczy sprzężony $\mathrm{z}$ naczepą skraca czas transportu, zmniejsza utrudnienia $\mathrm{w}$ ruchu drogowym z powodu osiąganej prędkości oraz emituje znacznie mniej zanieczyszczeń.

Badania wykonano na ciągniku rolniczym i samochodzie dostawczym typu pick-up. Silnik ciągnika John Deere to nowoczesna jednostka, zasilana układem wtryskowym typu common rail o maksymalnym ciśnieniu 1600 bar, który realizuje wtrysk wielofazowy, $\mathrm{z}$ turbodoładowaniem VGT. Na podstawie wykonanych badań w rzeczywistych warunkach eksploatacji stwierdzono, że korzystniejsze parametry ekologiczne ma przebadany samochód dostawczy niż ciągnik rolniczy. Analizując emisję drogową z całego przejazdu stwierdzono, że mniejszą emisję wszystkich związków szkodliwych miał samochód, emisja z ciągnika rolniczego była wielokrotnie większa. Największą różnicę odnotowano w odniesieniu do emisji CO, która dla ciągnika rolniczego była ponad 25 razy większa, emisja $\mathrm{HC}-11$ razy większa, natomiast emisja $\mathrm{NO}_{\mathrm{x}}$ prawie 6 razy większa. $\mathrm{Z}$ wyjątkiem emisji CO samochodu dostawczego emisja wszystkich związków toksycznych, zarówno dla samochodu, jak i ciągnika, przekracza limity normy Euro 4 (rys. 9). Również większe zużycie paliwa (emisja $\mathrm{CO}_{2}$ ) miał ciagnik rolniczy- ponad trzykrotnie w porównaniu z samochodem dostawczym. W aspekcie transportu ładunku i uczestnictwa w ruchu drogowym należy rozpatrywać również inne parametry przejazdu, takie jak czas i prędkość. Dla transportu z użyciem ciągnika rolniczego są one niekorzystne. Czas 


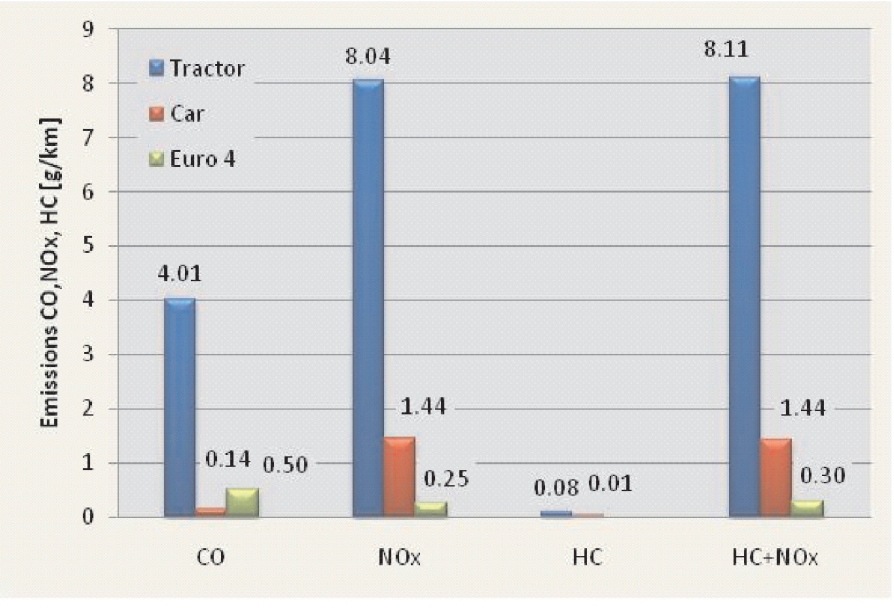

Fig. 9. The comparison of the on-road emissions of the light duty pickup truck and the farm tractor during the tests under real operating conditions

Rys. 9. Porównanie emisji drogowej samochodu dostawczego i ciagnika rolniczego podczas badań w rzeczywistych warunkach eksploatacji

of transportation of goods and traffic we also need to consider other parameters of the drive such as time and speed. For transporting of goods by a farm tractor these parameters are disadvantageous. The drive time by the tractor amounted to 72.6 minutes and the pickup truck 47.7 minutes. The average speed of the tractor was $24.6 \mathrm{~km} / \mathrm{h}$ and the pickup truck $37.3 \mathrm{~km} / \mathrm{h}$. These two parameters are important from the point of view of the traffic - farm tractors usually constitute a traffic speedreducing factor on the roads.

From the performed tests it results that transportation of goods of the mass of $4000 \mathrm{~kg}$ and, most likely also of lower mass, is more advantageous if a light duty truck is used for that purpose. The use of a pickup truck is characterized by a much lower emission of all the exhaust components and lower fuel consumption. It reduces the driving time and the fuel consumption and it is, thus, more economical. It also eliminates the traffic inconvenience resulting from low tractor speeds.

In the tests of the exhaust emissions under real operating conditions of machines (Fig. 10) when realizing fieldwork, we can observe that the engines of these machines operate mainly at steady speeds (which is advantageous for the exhaust emission level) and variable load - thus these conditions are different than those provided in the homologation tests. The greatest emission was recorded when changing the parameters of the engine i.e. changing of the settings of the operating machinery. Besides, the authors observed that the emissions under real operating conditions are much higher than the applicable limits- this particularly pertains to the emission of $\mathrm{NO}_{x}$.

One of the groups of non-road machinery that is quite high in number is the construction and earthworks machines. They are usually powered by turbocharged direct injected diesel engines. Depending on the size of the machine and its role these engines are of the power output of 40 to $1000 \mathrm{~kW}$. In terms of design they are different than traction engines. The operation of engines of several selected Caterpillar przejazdu ciągnikiem wynosił 72,6 min, a samochodem 47,7 min. Średnia prędkość przejazdu ciągnikiem to $24,6 \mathrm{~km} / \mathrm{h}$, a samochodem $37,3 \mathrm{~km} / \mathrm{h}$. Te dwa parametry są istotne $\mathrm{z}$ punktu widzenia ruchu drogowego - ciągniki rolnicze są zwykle obiektami hamującymi i opóźniającymi ruch.

$\mathrm{Z}$ przeprowadzonych badań wynika, że transport ładunków o masie $4000 \mathrm{~kg}$, a zapewne również o mniejszej, jest korzystniejszy samochodem dostawczym. Transport samochodem dostawczym charakteryzuje się znacznie mniejszą emisją wszystkich gazowych związków toksycznych i mniejszym zużyciem paliwa, skraca czas przejazdu i zmniejsza zużycie paliwa, jest zatem bardziej ekonomiczny. Pozwala także na wyeliminowanie utrudnień w ruchu drogowym wynikających z tego, że ciągniki są pojazdami wolnobieżnymi.

Z badań emisji związków toksycznych spalin w rzeczywistych warunkach pracy maszyn (rys. 10), w czasie wykonywania prac polowych, wynika, że silniki tych maszyn pracują głównie ze stałą prędkością obrotową

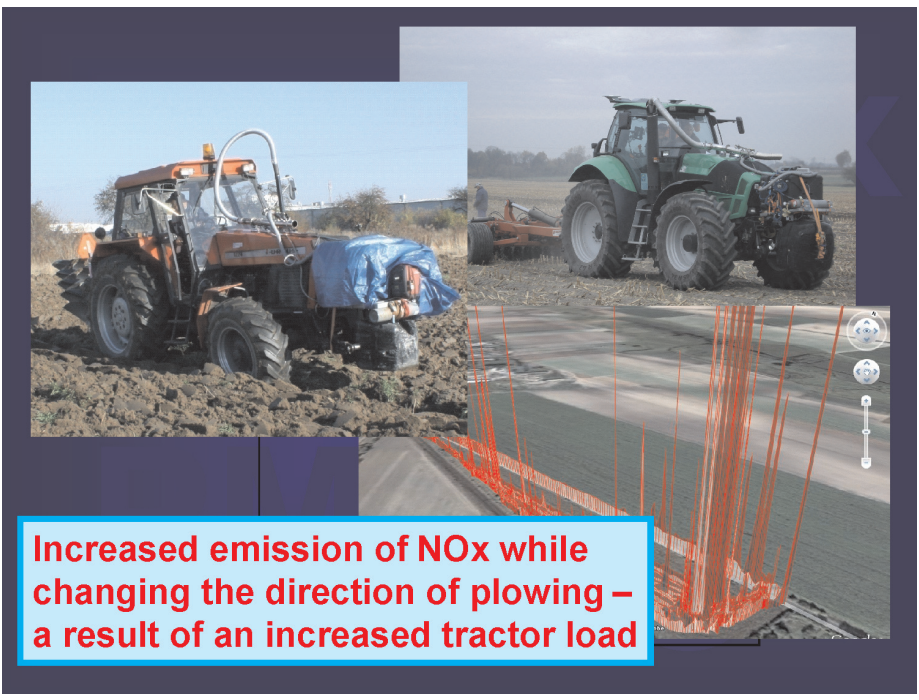

Fig. 10. Farm tractor emissions testing during fieldwork

Rys. 10. Badania emisji spalin podczas pracy polowej ciagnika rolniczego

(co sprzyja ograniczeniu emisji związków toksycznych), a zmienne jest obciążenie - są to zatem warunki odmienne niż w badawczych testach homologacyjnych. Największą emisję zarejestrowano podczas zmian parametrów pracy silnika, np. podczas zmiany nastaw urządzeń wykonujących pracę. Ponadto ustalono, że emisja w rzeczywistych warunkach eksploatacji jest znacznie większa niż obowiązujące limity - dotyczy to szczególnie $\mathrm{NO}_{\mathrm{x}}$.

Jedną z liczniejszych grup pojazdów o zastosowaniach pozadrogowych są maszyny budowlane i do robót ziemnych. Są one napędzane głównie silnikami ZS, turbodoładowanymi z bezpośrednim wtryskiem paliwa. W zależności od wielkości maszyny oraz jej przeznaczenia silniki te osiągają moc od 40 do 1000 kW. Pod względem konstrukcyjnym różnią się one od silników trakcyjnych. Analizowano pracę silników 

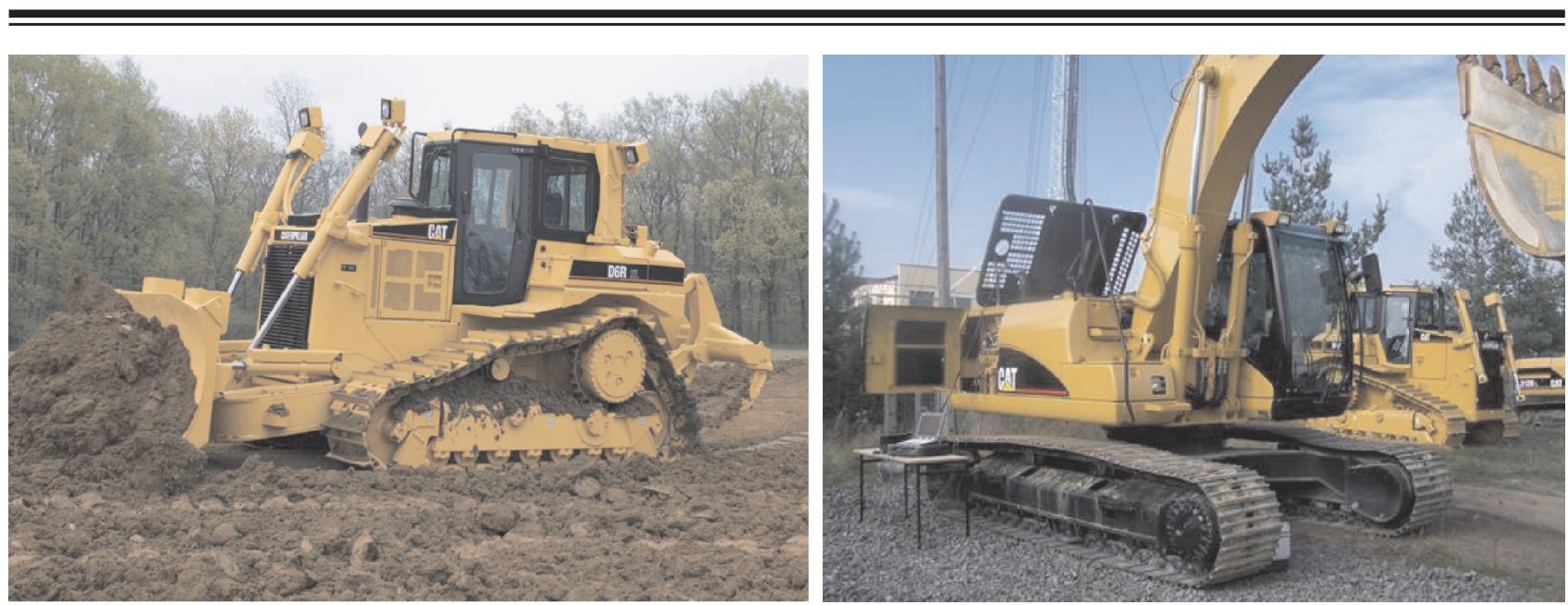

Fig. 11. Objects of the investigations: a bulldozer and an excavator by Caterpillar Rys. 11. Obiekty badań: spycharka i koparka firmy Caterpillar

machines were analyzed (Fig. 11): D6N (bulldozer), D6R (bulldozer), 325C (excavator).

A detailed analysis of the histograms of the engine operation can constitute a basis for the proposal of a field test of various non-road machines. Such a test should consider the most frequently used engine operating range. The ECE R96 test does not entirely reflect the real operating conditions of engines. The engines of the excavators operated for

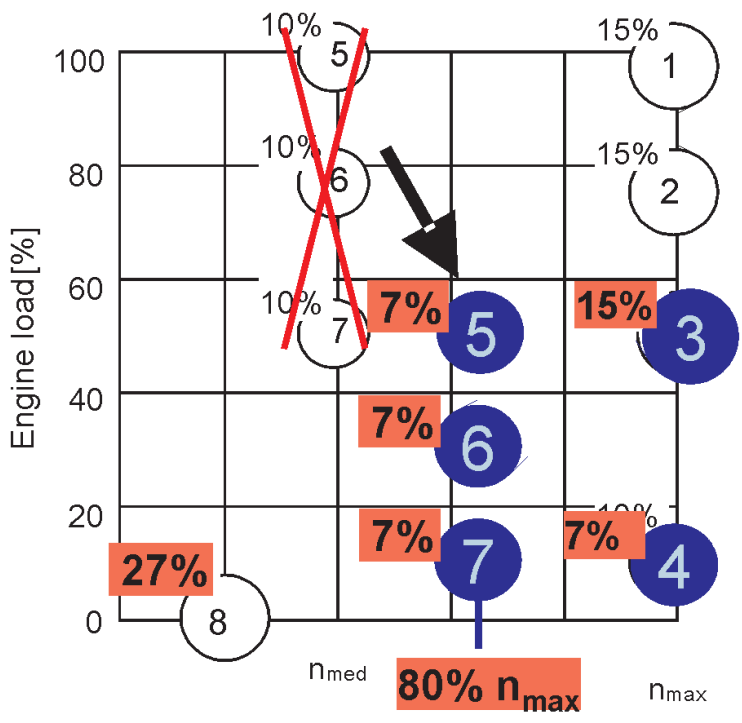

Engine speed [\%]

Fig. 12. A proposal of a new homologation test for excavator engines Rys. 12. Propozycja nowego testu homologacyjnego silników koparek

approximately $35 \%$ of the total operating time at idle engine speed and load not exceeding $50 \%$. The rest of the operating time was medium engine speeds that were $60 \%-70 \%$ of the engine speed of the maximum power. Based on the above data a non-laboratory exhaust emission test was developed (Fig. 12); the realization of the test is possible thanks to the hydraulics of the machine drivetrains (controlled engine load). In the tests the emission of nitric oxides and opacity are measured (as a substitute for the PM measurement). kilku wybranych jednostek napędowych pojazdów firmy Caterpillar (rys. 11): D6N (spycharka), D6R (spycharka), 325C (koparka).

Szczegółowa analiza zapisów histogramów pracy silników może być podstawą do opracowania propozycji testów polowych różnych maszyn pozadrogowych. Test taki powinien uwzględniać najczęściej wykorzystywany zakres pracy silnika. Test ECE R96 nie w pełni odzwierciedla rzeczywiste warunki pracy silnika. Silniki koparek przepracowały około $35 \%$ całkowitego czasu pracy z prędkością obrotową biegu jałowego i obciążeniem nieprzekraczającym 50\%. Pozostały czas pracy to praca $\mathrm{w}$ zakresie średnich prędkości obrotowych wału korbowego, stanowiących 60\%-70\% prędkości obrotowej wału korbowego mocy maksymalnej. Opierając się na powyższych danych, opracowano pozalaboratoryjny test toksyczności spalin (rys. 12); wykonanie testu jest możliwe dzięki wykorzystaniu właściwości hydraulicznych układów napędowych maszyn (kontrolowane obciążenie silnika). W teście dokonuje się pomiaru emisji tlenków azotu oraz stopnia zaczernienia spalin (jako substytutu emisji cząstek stałych).

Inną grupę maszyn stanowią maszyny do zastosowań specjalnych, m.in. kombajny leśne. Pomiarów emisji dokonano w rzeczywistych warunkach eksploatacji maszyny, pod-

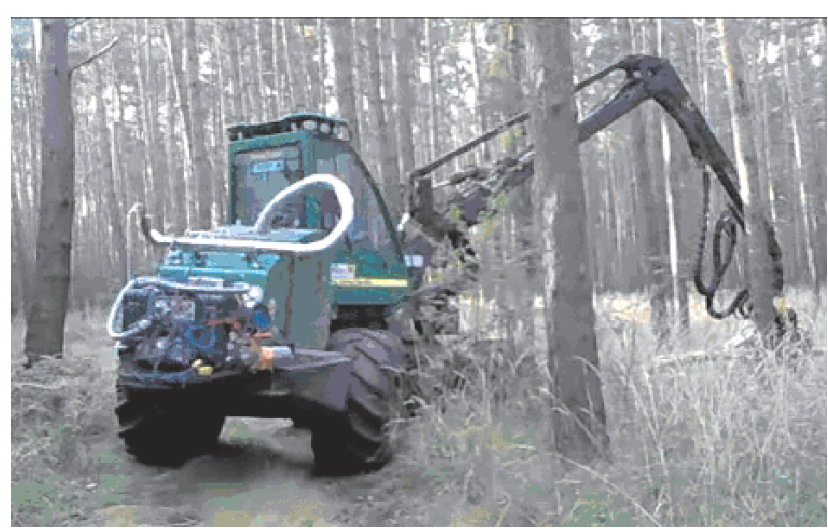

Fig. 13. Forest harvester during the tests cutting trees Rys. 13. Kombajn leśny podczas badań przy wycinaniu drzew 
Yet another group of machines is special purpose machinery such as forest harvesters. The exhaust emission measurements were performed under real operating conditions of the machine during forest works while cutting trees and branches as well as chopping tree trunks of $2 \mathrm{~m}$ in length. The machine ready for the tests with the testing equipment fitted and while operating in the forest has been presented in Fig. 13. The works were carried out in a pinewood forest. The processed trees were of diameter of approximately $20-30 \mathrm{~cm}$ cut on a relatively small area of approximately 1 ha (in the tests the machine covered a distance of $2.3 \mathrm{~km}$ ).

In many countries forest works are carried out with handheld chainsaws driven by gasoline engines. Forest harvesters are still quite rare in Europe, its eastern part in

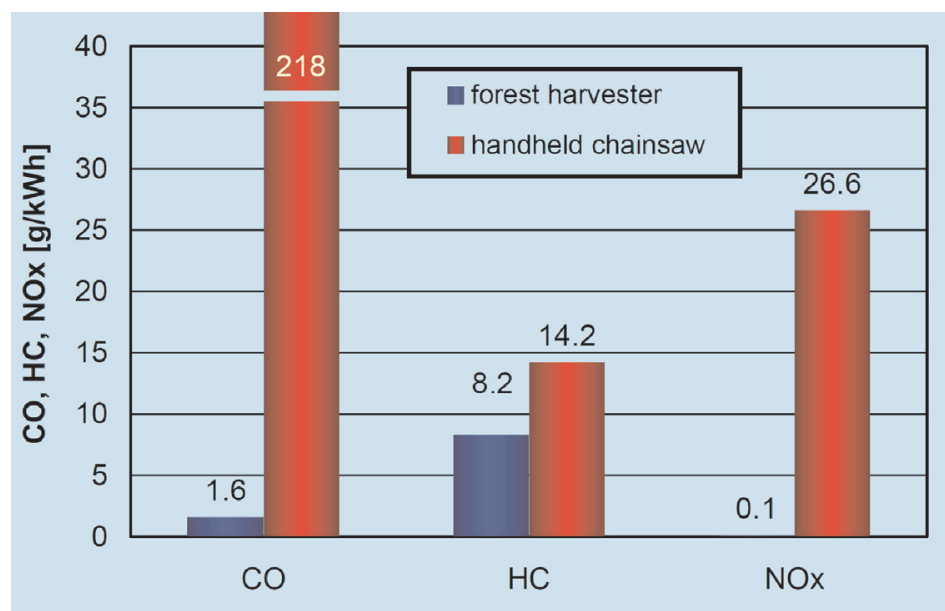

Fig. 14. The comparison of the exhaust emissions from a handheld chainsaw and a forest harvester under real operating conditions

Rys. 14. Porównanie emisji związków toksycznych spalin z silnika ręcznej piły tańcuchowej i kombajnu leśnego podczas pracy w rzeczywistych warunkach eksploatacyjnych

particular. In Poland in 2008 there were only 157 forest harvesters i.e. 1 in 580,000 ha of forest land. For comparison, the authors also performed exhaust emission tests from a handheld chainsaw under real operating conditions. This was a chainsaw driven by a two stroke gasoline engine of the power rating of $2.5 \mathrm{~kW}$. The comparison of the exhaust emissions from the handheld chainsaw and the forest harvester has been shown in Fig. 14. As far as the chainsaw is concerned its exhaust emissions are much higher than the emissions from the harvester engine e.g. for $\mathrm{HC}$ this emission is several hundred times higher and for $\mathrm{CO}$ over one hundred times higher. The smallest differences were recorded for the emission of $\mathrm{NO}_{\mathrm{x}}$. In order to stress the difference in the ecological parameters of the compared machines we need to relate to their efficiency. It is estimated that the efficiency czas prac leśnych polegających na wycince drzew, obcinaniu gałęzi i dzieleniu pni na bale o długości $2 \mathrm{~m}$. Maszynę przygotowaną do badań, z zamontowaną aparaturą badawczą, oraz $\mathrm{w}$ trakcie wykonywania pracy przedstawiono na rys. 13. Praca była wykonywana w lesie, w którym dominował drzewostan sosnowy. Wycinane były drzewa o średnicy ok. 20-30 cm na stosunkowo niedużym obszarze ok. 1 ha (podczas badań pojazd przejechał odległość 2,3 km).

W wielu krajach prace leśne polegające na wycince drzew są wykonywane $\mathrm{z}$ bardzo dużym udziałem ręcznych pił łańcuchowych napędzanych silnikami ZI. Kombajny leśne to nadal rzadkość w wielu krajach Europy, głównie Europy środkowo-wschodniej, np. w Polsce w 2008 r. było tylko 157 kombajnów leśnych, czyli jeden na około 580000 ha lasów. W celu porównawczym wykonano również badania emisji związków toksycznych z silnika ręcznej piły łańcuchowej w rzeczywistych warunkach pracy. Była to piła napędzana dwusuwowym silnikiem ZI o maksymalnej mocy 2,5 kW. Porównanie emisji $\mathrm{z}$ silnika piły i kombajnu zamieszczono na rys. 14. W odniesieniu do ręcznej piły łańcuchowej emisja wszystkich związków toksycznych jest znacznie większa niż emisja z silnika kombajnu, np. dla HC emisja ta jest kilkaset razy większa, a dla CO ponad sto razy większa. Najmniejsze różnice odnotowano dla emisji $\mathrm{NO}_{\mathrm{x}}$. Aby uwidocznić różnicę właściwości ekologicznych porównywanych maszyn, należy odnieść się do ich wydajności. Szacuje się, że wydajność kombajnu jest równoważna wydajności 4 pił łańcuchowych. Ponadto na niekorzyść ręcznych pił łańcuchowych przemawiają także względy dotyczące bezpieczeństwa i higieny pracy.

Podobne badania porównawcze pracy wykonano dla lokomotywy manewrowej oraz ciągnika szynowo-drogowego o mocy około $100 \mathrm{~kW}$. Ze względu na odmienne wartości siły pociągowej tych pojazdów analizy emisji spalin dokonano przy założeniu znacznego wydłu-

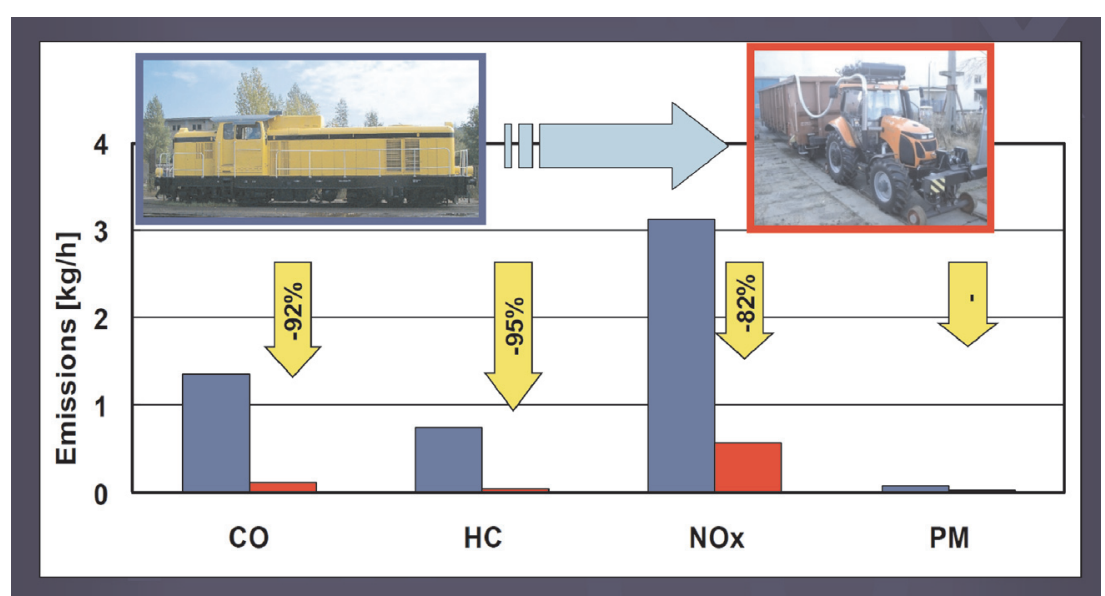

Fig. 15. The environmental consequence of the replacement of the shunting locomotives with rail tractors

Rys. 15. Skutki środowiskowe zastapienia lokomotyw manewrowych lekkimi pojazdami szynowymi 
of a forest harvester equals that of 4 handheld chainsaws. Besides, the occupational safety considerations clearly count against handheld chainsaws.

Similar comparative investigations were carried out for a shunting locomotive and a rail tractor of the power output of approximately $100 \mathrm{~kW}$. Due to different values of the tractive force of these vehicles the analysis of the exhaust emissions was done assuming a much longer operation time of the rail tractor. If we replace the shunting locomotive with the tractor we can obtain a reduction of the carbon monoxide and hydrocarbons emission by $90 \%$. The emission of nitric oxides is lower by more than $80 \%$ and the PM emission by $70 \%$ (Fig. 15).

Due to the specificity of the operation of armored vehicles an attempt was made to evaluate the operation of an armored vehicle
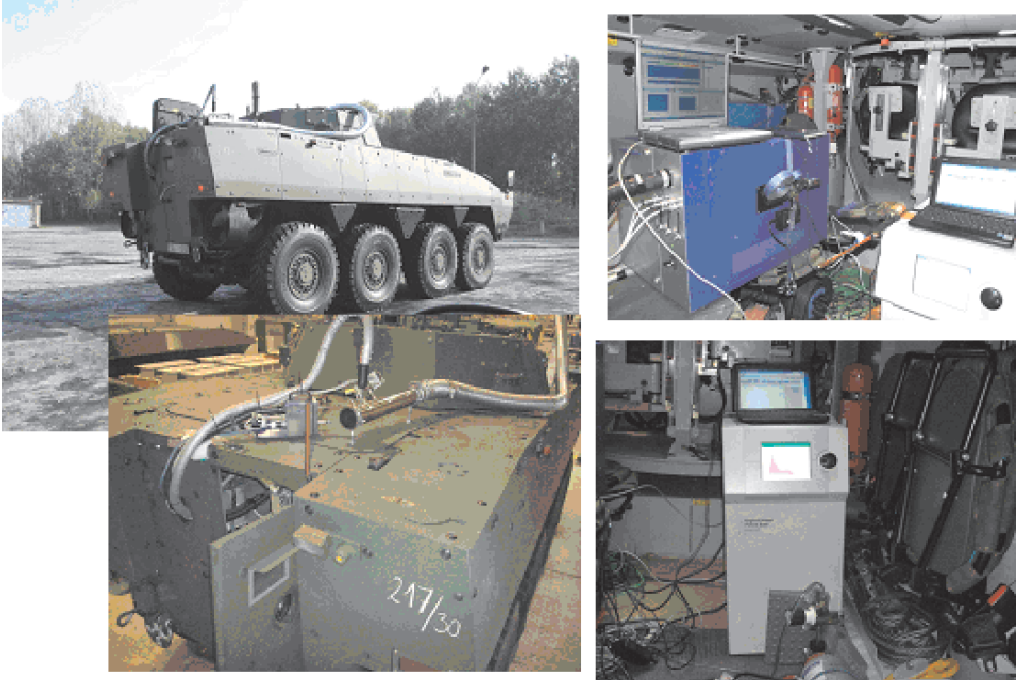

Fig. 16. Exhaust emission tests on armored vehicles under combat simulating conditions Rys. 16. Badania emisji spalin pojazdów bojowych $w$ warunkach poligonowych

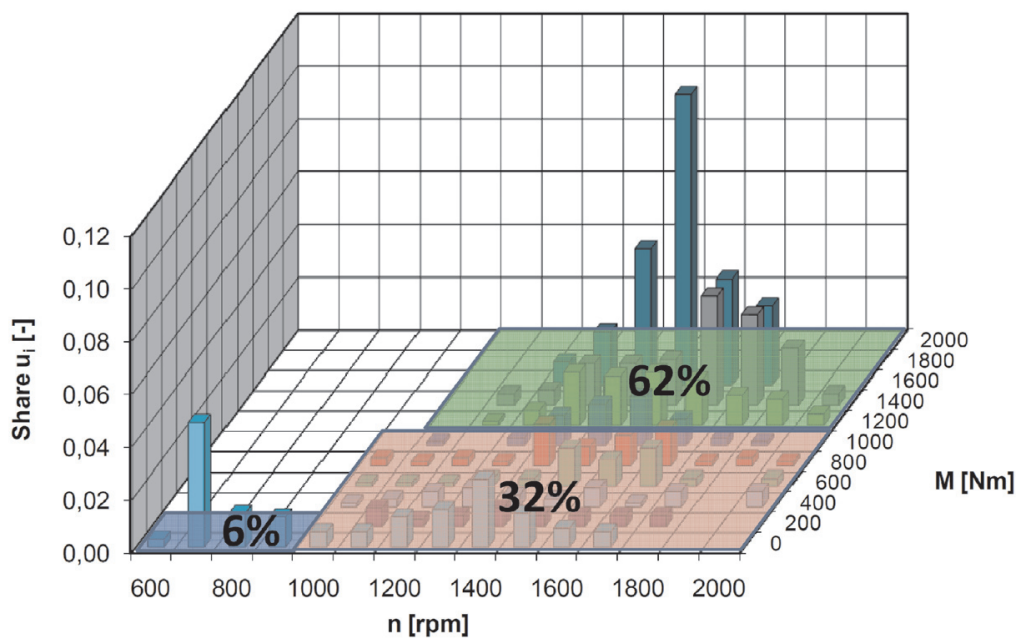

Fig. 17. The operating conditions of the armored vehicle engines that are the basis for the development of the test

Rys. 17. Warunki pracy silników pojazdów bojowych stanowiace podstawę opracowania testu toksyczności

and its impact on the fuel consumption and exhaust emissions. Knowing these values we can assess the character of operation of these vehicles (Fig. 16). The aim of the study was to answer the question to what extent the change in the operating conditions influences the fuel consumption and exhaust emissions in the armored vehicle.

Based on the tests of the operating conditions of the armored vehicles the authors determined the ranges that served for the development of a new test for this type of vehicles (Fig. 17). This test is composed of three operating modes under which the exhaust emission of the vehicle needs to be measured and then using the weighted coefficients (determining the length of operation in each mode) a weighted average is determined for the whole test. Lack of standards żenia czasu pracy ciągnika szynowo-drogowego. W wyniku zastąpienia lokomotywy manewrowej ciągnikiem można uzyskać obniżenie emisji tlenku węgla i węglowodorów o ponad $90 \%$, emisja tlenków azotu jest mniejsza o ponad $80 \%$, a emisja cząstek stałych o $70 \%$ (rys. 15).

Ze względu na specyfikę użytkowania wozów bojowych podjęto próbę oceny sposobu eksploatacji wozu bojowego oraz jego wpływu na zużycie paliwa i emisję składników szkodliwych. Znajomość tych wielkości pozwala ocenić sposób użytkowania wozów bojowych (rys. 16). Celem opracowania jest odpowiedź na pytanie: $w$ jakim stopniu zmiana warunków eksploatacji wpływa na zużycie paliwa i emisję składników szkodliwych przez silnik spalinowy pojazdu bojowego.

Na podstawie badań warunków pracy wozów bojowych ustalono zakresy, które posłużyły do opracowania nowego testu badawczego dla tego typu pojazdów (rys. 17). Test ten składa się z trzech trybów pracy, w których należy określić emisję wozu bojowego, a następnie, korzystając ze współczynników wagowych (określających długotrwałość pracy w każdych warunkach), oblicza się średnią ważoną emisję z całego testu. Brak norm porównawczych można zastąpić normami dotyczącymi badań silników na hamowni silnikowej.

\subsection{Badania statków powietrznych}

Obecne przepisy dotyczące wpływu środków transportu lotniczego na środowisko naturalne wprowadzone przez EPA (Environmental Protection Agency - Agencja Ochrony Środowiska), ICAO (International Civil Aviation Organization - Organizacja Międzynarodowego Lotnictwa Cywilnego) zawarte w JAR 34 (Joint Aviation Requirements - przepisy 


\begin{tabular}{|l|c|c|c|}
\hline & $\begin{array}{c}\text { Flight } \\
\text { speed } \\
130 \mathrm{~km} / \mathrm{h}\end{array}$ & $\begin{array}{c}\text { Vehicle speed } \\
130 \mathrm{~km} / \mathrm{h}\end{array}$ & $\begin{array}{c}\text { Comparison } \\
\text { of concentration }\end{array}$ \\
\hline $\begin{array}{l}\text { Engine } \\
\text { speed } \\
\left.\text { [min }{ }^{-1}\right]\end{array}$ & 2000 & 4000 & $\begin{array}{c}\text { plane / } \\
\text { vehicle }\end{array}$ \\
\hline $\begin{array}{l}\text { Average } \\
\text { concentration }\end{array}$ & 2.2 & 0.02 & $110 \times$ more \\
$\mathrm{CO}[\%]$ & 2900 & 5 & $580 \times$ more \\
$\mathrm{HC}[\mathrm{ppm}]$ & 400 & 40 & $10 \times$ more \\
$\mathrm{NO}_{\mathrm{x}}[\mathrm{ppm}]$ & 8.2 & 12 & $1.4 \mathrm{x}$ less \\
\hline $\mathrm{CO}_{2}[\%]$ & & & \\
\hline
\end{tabular}

Fig. 18. The comparison of the emissions from an aircraft and a vehicle

Rys. 18. Porównanie emisji z samolotu i z pojazdu samochodowego

for comparison can be compensated with standards related to engines tested on engine dynamometers.

\subsection{Aircraft emission tests}

Current legislation related to the impact of air transport on the natural environment introduced by EPA(Environmental Protection Agency), ICAO (International Civil Aviation Organization) set forth in JAR 34 (Joint Aviation Requirements), FAR 34 (Fuel Venting and Exhaust Emission Requirements for Turbine Engine Powered Airplanes) are mainly related to the noise and exhaust emissions (nitric oxides in particular). Comparing the emissions from an aircraft with the emissions from a passenger vehicle the aircraft emission are disadvantageous. For some of the exhaust components it could even be several hundred times higher (Fig. 18). The results of such analyses pushed the authors to embark on testing of aircraft under real operating conditions (Fig. 19).

\section{Conclusions}

In the new legislation the testing methodology for the compliance control of heavy-duty vehicles in operation diverges from that used in type approvals. Instead of testing of the engine on an engine dynamometer on-road testing was introduced. The exhaust emissions are measured by a portable exhaust emission measurement system PEMS. This is a significant difference as compared to the current status quo in this matter in relation to both light duty and heavy-duty vehicles (the methods of compliance control and homologation were supposed to be identical).

Current level of technology related to exhaust emission measurement enables a realization of on-road measurement of emissions in real traffic conditions $[2,9]$. The greatest inconvenience of this type of research are the costs of the equipment and adaptations for the system to fit in the vehicle. Such attempts are currently being made, for comparison of different measuring techniques for different vehicles, in all countries whose priority is environment protection. Hence, we can see a trend leading towards making the on-road określające normy emisji spalin), FAR 34 (Fuel Venting and Exhaust Emission Requirements for Turbine Engine Powered Airplanes - przepisy określające normy emisji spalin), dotyczą głównie emisji hałasu i związków szkodliwych spalin, ze szczególnym uwzględnieniem tlenków azotu. Porównując emisję z samolotu do emisji z samochodu osobowego, niekorzystnie przedstawia się emisja z samolotu, która jest dla niektórych związków nawet kilkaset razy większa (rys. 18). Wyniki takich analiz skłoniły do zajęcia się również tematem emisji ze statków powietrznych w rzeczywistych warunkach lotu (rys. 19).

\section{Podsumowanie}

W nowych przepisach metoda badań w ramach kontroli zgodności w eksploatacji pojazdów ciężkich różni się od stosowanej w homologacji typu. Zamiast badań silnika na hamowni silnikowej wprowadzono badania pojazdu w normalnym ruchu drogowym. Emisja zanieczyszczeń jest mierzona za pomocą przenośnego układu do pomiaru emisji zanieczyszczeń PEMS. Stanowi to istotną różnicę w stosunku do zasady obowiązującej dotychczas zarówno dla

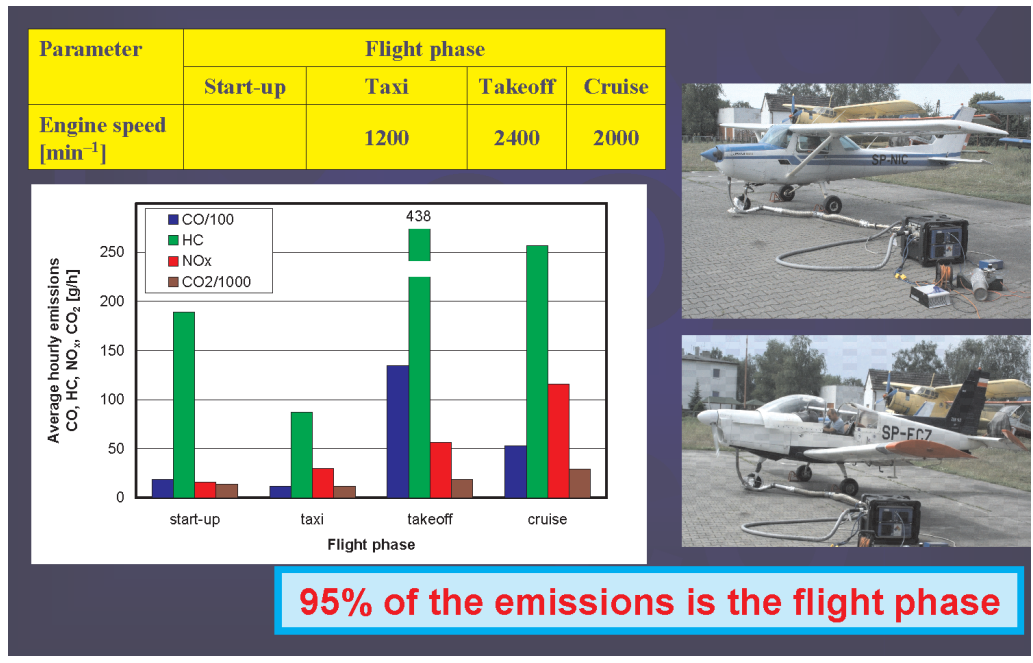

Fig. 19. The exhaust emission testing of aircraft under flight and stationary conditions Rys. 19. Badania emisji związków szkodliwych spalin z silników lotniczych $w$ warunkach lotu oraz $w$ warunkach stacjonarnych pojazdów lekkich, jak i ciężkich, zgodnie z którą metody stosowane w kontroli zgodności w eksploatacji i homologacji typu powinny być identyczne.

Obecny poziom techniki pomiarowej związanej z badaniem emisji związków szkodliwych spalin umożliwia realizację badań środków transportu w rzeczywistych warunkach eksploatacji [2, 9]. Największą niedogodnością takich badań jest wysoki koszt aparatury pomiarowej i przystosowanie jej do warunków zabudowy w pojeździe. Próby takie przeprowadza się obecnie we wszystkich państwach, w których ochrona środowiska stanowi priorytet działań, w celu porównania możliwości pomiarowych dla różnorodnych pojazdów i różnych urządzeń pomiarowych. W związku z powyższym dostrzegalny jest trend usankcjonowania pomiaru emisji związków szkodliwych w warunkach rzeczywistej eksploatacji pojazdów w Europie. Badania tego typu 
emission measurement in Europe an applicable and legally binding scheme. This type of testing enables determining of the actual emissions of all the exhaust components under real operating conditions. The tests also allow an evaluation of the specificity of the operation of a given means of transport in terms of time density of the engine load. Such information enables determining of the operating states of powertrains along with their share in the total operating time. Such information can be related to the stationary test procedures, which in the future could lead to the optimization of the operating points of engines used in different types of transport.

Stringent emission requirements in relation to traction engines will make sense and bring measurable benefits only if the component of the total emissions, being the emissions from non-road vehicle engines is reduced. A system of standards developed in relation to the automotive engines will constitute the basis for the setting of limits related to railroad engines, heavy machinery, construction machinery and other stationary non-traction engines. In reference to the mentioned group of engines it is also necessary to consider its life cycle that is much longer than in the case of vehicle engines. pozwalają określić poziom wartości emisji poszczególnych związków szkodliwych spalin w rzeczywistych warunkach ruchu. Ponadto umożliwiają ocenę specyfiki eksploatacyjnej środka transportu pod względem gęstości czasowej obciążenia silnika. Informacje te pozwalają na wyznaczenie stanów eksploatacyjnych zespołu napędowego wraz z ich udziałem w całkowitym czasie eksploatacji. Takie informacje mogą być odniesione do procedur testów stacjonarnych, co w przyszłości może umożliwić optymalizację punktów pracy silników eksploatowanych w różnych środkach transportu.

Rygorystyczne normy emisji w odniesieniu do grupy silników spalinowych napędzających samochody mają sens i mogą przynieść realne korzyści tylko wtedy, gdy również zmniejszeniu ulegnie składowa całkowitej emisji związana z pozadrogowymi zastosowaniami silników. System norm opracowany w odniesieniu do silników samochodowych będzie podstawą tworzenia odpowiednich limitów dotyczących silników w zastosowaniach kolejowych, w maszynach roboczych, budowlanych i innych oraz silników stacjonarnych. Odnośnie do wymienionej grupy silników konieczne jest uwzględnienie ich okresu eksploatacji, który jest znacznie dłuższy niż dla samochodu.

Paper reviewed

\section{Bibliography/Literatura}

[1] Dyrektywa 2007/46/WE Parlamentu Europejskiego i Rady z dnia 5 września 2007 r. ustanawiająca ramy dla homologacji pojazdów silnikowych i ich przyczep oraz układów, części i oddzielnych zespołów technicznych przeznaczonych do tych pojazdów („dyrektywa ramowa”). OJ L 263/1, 9.11.2007.

[2] Gao Y., Checkel M.D.: Experimental Measurement of OnRoad $\mathrm{CO}_{2}$ Emission and Fuel Consumption Functions, SAE Technical Paper Series 2007-01-1610.

[3] Johnson K., Durbin T., Cocker D., Miller J., Agama R., Moynahan N., Nayak G.: On-Road Evaluation of a PEMS for Measuring Gaseous In-Use Emissions from a Heavy-Duty Diesel Vehicle, SAE Technical Paper Series 2008-01-1300.

[4] Khair M., Khalek I., Guy J.: Portable Emissions Measurement for Retrofit Applications - The Beijing Bus Retrofit Experience, SAE Technical Paper Series 2008-01-1825.

[5] Merkisz J., Lijewski P., Fuć P., Pielecha J.: Exhaust Emission Tests from Agricultural Machinery under Real Operating Conditions. SAE Technical Paper Series 2010-01-1949.

Prof. Jerzy Merkisz, DSc., DEng. - Professor in the Faculty of Working Machines and Transportation at Poznan University of Technology.

Prof. Jerzy Merkisz - profesor na Wydziale Maszyn Roboczych i Transportu Politechniki Poznańskiej.

e-mail: jerzy.merkisz@put.poznan.pl
[6] Merkisz J., Pielecha J., Pielecha I.: Gaseous and PM Emission from Combat Vehicle Engines during Start and Warm-Up. SAE Technical Paper Series 2010-01-2283.

[7] Merkisz J., Pielecha J., Radzimirski S.: Pragmatyczne podstawy ochrony powietrza atmosferycznego w transporcie drogowym. Wydawnictwo Politechniki Poznańskiej, Poznań 2009.

[8] Pi-qiang Tan, Zhi-yuan Hu, Di-ming Lou, Bo Li: Particle Number and Size Distribution from a Diesel Engine with Jatropha Biodiesel Fuel, SAE Technical Paper Series 2009-01-2726.

[9] Rapone M., Ragione L., Meccariello G.: Characterization of Real-World Bus Driving Behavior for Emission Evaluation, SAE Technical Paper Series 2007-24-0112.

[11] Sharp C.A., Feist M.: Results of the HDIUT Gaseous PEMS Measurement Allowance Program and Update on PM Program Status, Sensors 4th Annual SUN (SEMTECH User Network) Conference, Ann Arbor 2007.

[12] Steininger N.: Automotive Particulate in European Legislation: State of the Art and Developments to Come. 13th ETH Conference on Combustion Generated Particles, Zurich 2009.

[10] Schöppe D., Greff A., Zhang H., Frenzel H., Rösel G., Achleitner E., Kapphan F.: Requirements for Future Gasoline DI Systems and Respective Platform Solutions. 32th Internationales Wiener Motorensymposium 2011, Vienna 2011.

[13] Yu Jinghong, Hosni E., Haskell J.: Application of Fuel and Cost Efficient Steering Technology - Variable Displacement Pump - to SUV/SUTS. World Automotive Congress Fisita, F2010-A-032, Budapest 2010.

[14] Zhao F.F.: Technologies for Near-Zero-Emission GasolinePowered Vehicles, SAE International, Warrendale 2007. 